\title{
PROGRAM PELALIANAN "KEDAS" (KEGIATAN SEHAT DIARE TUNTAS) SEBAGAI SARANA EDUKASI ANAK DALAM UPAYA PENANGGULANGAN PENYAKIT DIARE DI SD NEGERI 1 UBUD
}

\author{
P.K.P. Wirtarandita ${ }^{1}$, P.P.T. Saraswati ${ }^{2}$, C.I.D.Y. Dewi ${ }^{3}$, T.B.A.A. Prawira ${ }^{4}$, A.I.Y.D. Putra ${ }^{5}$, \\ D.P.Y. Kurniati ${ }^{6}$
}

\begin{abstract}
ABSTRAK
Anak-anak memiliki risiko tinggi terkena diare. Terdapat 1.102 kasus diare di Puskesmas Ubud I pada tahun 2017 dan merupakan jumlah kasus tertinggi di Kabupaten Gianyar. Faktor risiko diare antara lain adalah sanitasi lingkungan yang kurang baik dan makanan serta minuman yang tidak higienis. Sebuah program edukasi dengan mengkombinasikan dengan budaya bali berupa "Pelalianan KEDAS" dibuat untuk meningkatkan pengetahuan dan wawasan siswa-siswi SD Negeri 1 Ubud tentang pentingnya menjaga kebersihan diri guna mencegah penyakit diare. Kegiatan ini juga sekaligus digunakan untuk melestarikan lagu dan permainan tradisional Bali. Metode yang diterapkan yaitu: 1) Wacana (berbicara); 2) Ngurukin (mencontohkan); 3) Masolah (mempraktekkan); 4) Uning (mengerti). Hasil menunjukkan bahwa pada setiap tahap pelaksanaan anak-anak mampu mengikuti, antusias, dan mengerti terhadap program yang telah dilaksanakan. Keaktifan program KEDAS di media sosial youtube ditunjukkan dengan total 100 kali telah dilihat dan 40 orang menyukai. Program ini juga telah direkomendasikan kepada sekolah untuk dimasukkan ke dalam muatan lokal.
\end{abstract}

Kata kunci : Diare, Edukasi, Anak, Tradisional, Budaya.

\author{
ABSTRACT \\ Children have higher risk in contracting Diarrhoea. There are 1.102 Diarrhoea cases in 2017 at Puskesmas \\ Ubud I and constitute highest amount of cases found in Gianyar regency. The factors of Diarrhoea are due to \\ deficient sanitation in environment and unhygienic foods also beverages. An education program combined \\ with the Balinese traditional culture in form of "Pelalianan KEDAS" aimed to increase the knowledge and \\ insight of students in SD Negeri 1 Ubud concerning the importance of personal hygiene in order to prevent \\ 'Program Studi Sarjana Kedokteran dan Profesi Dokter, Fakultas Kedokteran, Universitas Udayana, \\ pandeparama98@gmail.com \\ ${ }^{2}$ Program Studi Sarjana Kedokteran dan Profesi Dokter, Fakultas Kedokteran, Universitas Udayana, \\ putrititamia12@yahoo.co.id \\ ${ }^{3}$ Program Studi Sarjana Kedokteran dan Profesi Dokter, Fakultas Kedokteran, Universitas Udayana, \\ coktikaa@gmail.com \\ ${ }^{4}$ Program Studi Sarjana Kedokteran dan Profesi Dokter, Fakultas Kedokteran, Universitas Udayana, \\ tubagusprawira@icloud.com \\ ${ }^{5}$ Program Studi Sarjana Kedokteran dan Profesi Dokter, Fakultas Kedokteran, Universitas Udayana, \\ indrayudhistirawin@gmail.com \\ ${ }^{6}$ Program Studi Kesehatan Masyarakat, Fakultas Kedokteran, Universitas Udayana, desak.yuli@unud.ac.id
}


diarrhoea disease. This program at once used to preserve traditional Balinese songs and games. The method that will be implemented those are: 1) Wacana (discourse); 2) Ngurukin (exemplify); 3) Masolah (practice); 4) Uning (understanding). The result shown that each steps implementation of program children are able to follow, enthusiastic and understand the program that has been done. The liveliness of KEDAS program in social media, YouTube, shown with a total 100 viewers and 40 likes.

Keywords : Diarrhoea, Education, Children, Traditional, Culture.

\section{PENDAhULUAN}

Diare adalah buang air besar dengan konsistensi lembek atau cair, bahkan dapat berupa air saja dengan frekuensi lebih sering dari biasanya (tiga kali atau lebih) dalam satu hari (Depkes RI, 2011). Diare merupakan gejala infeksi di saluran usus, yang dapat disebabkan oleh berbagai organisme bakteri, virus dan parasit yang bersifat oro-fecal. Faktor risiko penyebaran penyakit ini adalah sanitasi lingkungan yang kurang baik, proses pencucian tangan yang tidak baik dan kurangnya pengetahuan, makanan yang tidak higienis, dan tempat penyimpanan makanan dingin yang kurang (Rahman, 2016). Diare dapat berlangsung beberapa hari dan dapat menyebabkan dehidrasi (WHO, 2017).

Secara global, ada hampir 1,7 miliar kasus penyakit diare masa kanak-kanak setiap tahun. Menurut Dinas Kesehatan Provinsi Bali pada tahun 2016 kasus diare dan gastroenteritis di RSU Provinsi Bali sebanyak 3061 dan kasus gastritis di Puskesmas Provinsi Bali sebanyak 34. 087 (Dinkes Bali, 2017). Terdapat 1.102 kasus diare di Puskesmas Ubud I pada tahun 2017 yang merupakan jumlah tertinggi di Kabupaten Gianyar (Dinkes Gianyar, 2018).

Sebuah program yang berguna sebagai sarana edukasi sekaligus mengangkat budaya tradisional Bali yakni pelalianan KEDAS (Kegiatan Sehat Diare Tuntas). Pelalianan artinya bermain dalam bahasa bali dan kata kedas berasal dari bahasa bali yang artinya bersih. Program kegiatan ini diharapkan berguna sebagai media edukasi dan hiburan bagi anak-anak di SD Negeri 1 Ubud. Sekolah ini menjadi lokasi pengabdian karena dekat dengan Puskesmas Ubud I yang terdapat kejadian diare tertinggi pada tahun 2017 di Kabupaten Gianyar. Ubud telah terkenal hingga mancanegara akan budaya dan kearifan lokalnya.

Tujuan program pelalianan KEDAS adalah untuk meningkatkan pengetahuan dan wawasan siswasiswi SD Negeri 1 Ubud tentang pentingnya menjaga kebersihan diri guna mencegah penyakit diare, serta melestarikan lagu dan permainan tradisional. Program ini diharapkan dapat berlanjutkan dan diterapkan pada semua tingkatan kelas sebagai kegiatan tambahan dalam muatan lokal diluar kegiatan belajar mengajar.

\section{METODE}

Dalam pelaksanaan program KEDAS anak-anak kelas III SD di SD Negeri 1 Ubud menjadi objek dari kegiatan ini. Pemilihan sudah dilakukan sebelum pembuatan proposal program KEDAS. Dengan beberapa kriteria yaitu lokasi zona rawan diare, sikap peserta didik dalam menjaga sanitasi diri, peran sekolah dalam meminimalisir keberadaan diare, tingkat antusiasme siswa terhadap pelalianan tradisional, dan jumlah siswa kelas III sekolah dasar minimal 100 orang. Adapun kriteria dari anakanak yang bisa mengikuti program ini adalah anak-anak yang berusia minimal 6 tahun dan maksimal 
10 tahun, tidak dalam keadaan sakit dalam pelaksanaan program, sehat jasmani rohani, mampu menuruti arahan dan perintah dipaparkan oleh fasilitator selama kegiatan berlangsung, sukarelawan anak tanpa adanya paksaan/menerima secara berat hati.

Pelaksanaan program KEDAS terdiri dari tahapan sebagai berikut:

\section{a) Wacana (berbicara)}

Wacana dalam artian Bahasa Bali berarti berbicara. Disini kami sebagai fasilitator kegiatan memperkenalkan tentang apa itu penyakit diare, disebabkan oleh apa, pentingnya mencuci tangan, cara mencuci tangan yang baik, serta gizi seimbang. Kegiatan ini kami laksanakan pada tanggal 18 Mei 2019. Disini kami mengajak anak-anak berperan aktif dengan bertanya dan menjawab. Kami juga memberikan pertanyaan-pertanyaan terkait diare kepada anak-anak sebelum pemaparan materi untuk mengetahui tingkat pengetahuan mereka mengenai diare.

\section{b) Ngurukin (mencontohkan)}

Ngurukin dalam Bahasa Bali berarti mencontohkan. Kegiatan ngurukin dilaksanakan pada tanggal 18 Mei 2019 dan 31 Mei 2019. Pada tanggal 18 Mei 2019 fasilitator mengajarkan lirik lagu yang akan digunakan untuk permainan, fasilitator melatih anak untuk membaca terlebih dahulu lalu melantunkannya. Lagu yang digunakan merupakan sekar rare yang telah dimodifikasi bagian liriknya dan lagu diiringi oleh alat musik gitar dan ketipung. Sekar rare merupakan lagu-lagu yang menggunakan bahasa daerah bali, memakai sajak bebas, dimana setiap lagu di dalamnya selalu diselipkan pesan moral yang biasanya ditujukan untuk anak-anak. Beberapa lagu sekar rare yang digunakan adalah yuk mari kesini, curik-curik, goak, umpilaung, tultaltil. Fasilitator juga menjelaskan terperinci kepada peserta didik tentang pesan yang termuat pada lirik lagu.

Pada tanggal 31 Mei 2019 fasilitator mengajarkan langkah-langkah permainan dimana konsep permainannya adalah "Goak-goakan demen memaling" (Gagak- gagak yang suka mencuri) yang merupakan permainan yang konon berasal dari Daerah Bali Utara. Kisah mulanya adalah ajakan seorang raja bernama Ki Barak Pandji Sakti yang mengajak pasukannya untuk bermain goak-goakan. Sang Raja menjadi goaknya sedangkan komandan pasukannya menjadi pemimpin pasukan yang menjadi lawan sang raja. Komandan dan anak buahnya diberikan kesempatan oleh Sang raja untuk bersembunyi disemak-semak dan Sang raja akan mencari mereka untuk menangkap mereka. Sang raja tampak sangat gesit untuk bisa mendapatkan anak buah komandan yang bersembunyi disemaksemak. Apabila raja memenangkan permainan ini dengan semakin banyak mengambil anak buah komandannya maka raja berhak meminta apapun termasuk wilayah kekuasaan sekalipun. Semangat ini yang terus dipupuk oleh raja agar anak buahnya berjuang gigih melawan musuhnya. Berdasar atas dari folklore ini, nilai-nilai kegigihan kami adaptasi untuk dapat meminimalisir kasus diare pada anak-anak. Untuk program pelalianan KEDAS terdapat 2 peran utama yang bisa diperankan oleh anak-anak yakni I Bacté dan I Imun. Pemilihannya dilakukan dengan sistem suit (sut tangan). Dalam permainan I Bacté yang akan memiliki anak buah dan I Imun harus merebut anak buahnya I Bacté yang memiliki kemampuan untuk bersembunyi di dalam lingkaran. Kalau tidak bisa merebut menandakan antibodi kita lemah (pengasosiasian) sehingga nanti I Bacté menang dan menginfeksi kita sehingga terjadilah diare. Selama permainan akan diiringi lagu-lagu modifikasi dari sekar rare yang sudah diajarkan kepada anak-anak.

c) Masolah (mempraktekkan)

Masolah dalam artian Bahasa Bali artinya mempraktekkan. Tahap ini dilaksanakan pada tanggal 31 Mei 2019 dimana pada tahap ini anak dilatih daya ingat, kelincahan gerak, kerjasama, dan waspada. Jadi perkembangan motorik kasar amat sangat berperan. Pada tahap masolah fasilitator mengajak anak-anak melakukan permainan dimana pada permainan anak-anak membentuk tiga lingkaran besar dan dilakukan pemilihan pemeran I Bacté dari masing-masing lingkaran sehingga didapatkan tiga orang sebagai I Bacté dan memilih satu orang sebagai I Imun. Dalam permainan I Imun dibekali alat pemukul menggunakan spon tipis yang di berikan lapban. I Imun harus mengejar dan memukul I Bacté, ketika I Bacté terkena pukulan dari I Imun itu menandakan I Bacté sudah kalah dari permainan. 
Namun I Bacté mempunyai kemampuan untuk bersembunyi dari I Imun di dalam tiga lingkaran yang ada namun hanya selama 5 detik. Setelah selesai mempraktekkan permainan anak-anak kami ajak melakukan praktek mencuci tangan yang benar dan kami berikan handuk serta hand sanitizer sehingga anak-anak lebih terpacu untuk selalu mencuci tangan mereka sesuai 6 langkah mencuci tangan.

\section{d) Uning (mengerti)}

Uning dalam Bahasa bali berarti mengerti. Tahap uning dilaksanakan pada 16 Juli 2019. Diharapkan mereka akan mengerti tujuan dari program KEDAS ini. Jadi diakhir permainan fasilitator akan menjelaskan masing-masing peran dari permainan. Lalu mereka diharapkan akan mendapat pengetahuan yang lebih sehingga dapat membangun rasa eling (ingat) dalam mengkonsumsi makanan yang dianggap kurang higienis. Selain itu kami akan mengevaluasi pengetahuan setelah dilaksanakan program secara lisan mengenai permainan dan materi diare yang telah dijelaskan.

\section{HASIL DAN PEMBAHASAN}

\subsection{Hasil diperoleh dalam program KEDAS}

Setelah melakukan kegiatan dengan menggunakan metode berupa wacana (berbicara), ngurukin (mencontohkan), masolah (mempraktekkan), dan terakhir adalah tahap uning (tahu/mengerti) dapat diidentifikasikan hasil-hasil yang didapat selama kegiatan berlangsung yang dijabarkan dalam setiap metode berupa:

\section{a) Wacana (berbicara)}

Dalam tahap wacana ini, peserta diharapkan mampu mendengarkan arahan fasilitator dalam pemberian materi sosialisasi yang berkaitan dengan materi diare mulai topik yang luas hingga mendalam. Hal itu dimulai dengan memperkenalkan definisi diare yang tepat kepada peserta yang awalnya menganggap diare hanya "feses seperti air", sehingga dapat terjadi peningkatan pengetahuan. Selanjutnya adalah melakukan recall kembali cuci tangan tepat yang seharusnya dilakukan sebelum dan sesudah beraktivitas. Dalam pengenalan substansi materi, fasilitator memperkenalkan kepada peserta penanganan awal diare dengan menggunakan oralit meliputi cara membuatnya dengan takaran yang tepat. Di dalam sosialisasi, guna melatih rasa ingin tahu dan keaktifan maka fasilitator memberikan pertanyaan kepada peserta. Selain itu, pengenalan konsep piramida makanan menggantikan 4 sehat 5 sempurna juga diajarkan. Tampak dalam pelaksanaan tahap wacana peserta antusias memperhatikan dan memahami isi materi, dilihat dari hasil tanya jawab diakhir sosialisasi dengan menunjuk secara acak peserta dan didapatkan hasil antara 10 orang yang ditanya 9 orang berhasil tepat menjawab sesuai dengan isi materi sosialisasi. Diakhir kegiatan bila ada peserta tidak mengerti tentang satu hal mereka bertanya kepada fasilitator, lalu fasilitator menjawab dengan melemparkan terlebih dahulu pertanyaan kepada peserta kembali, peserta berani mengemukakan pendapatnya dan fasilitator hanya menambahkan/ meluruskan jawaban peserta.

b) Ngurukin (mencontohkan)

Supaya memudahkan daya tangkap peserta tentang program yang akan dilakukan maka fasilitator mencontohkan dengan menuliskan lagu di papan dan didapatkan hasil peserta berinisiatif untuk mencatat. Dalam proses pencatatan didapatkan peserta ketika mencatat lagu tampak cepat dan tepat menulis, walau terdapat beberapa peserta yang tertinggal sehingga diberi tambahan waktu untuk mengejar. Dilihat dari proses yang diajarkan daya serap peserta sangat baik, cepat sekali menangkap dan menghapal 4 lirik lagu yang baru diberikan. Selain itu, peserta mampu menghapal dan 
melantunkan lirik dengan cara melagukannya secara tepat sambil diiringi instrumen musik gitar. Bila terjadi kesalahan pelantunan lagu maka fasilitator akan mengoreksi sehingga mudah dipahami oleh peserta untuk dinyanyikan kembali. Berdasarkan pengamatan, peserta sudah cukup mampu berfikir analogi dengan mengaitkan materi sosialisasi yakni penyebab diare yang didominasi oleh bakteri lalu terdapat imun yang memproteksi tubuh sehingga dibuat lakon dalam permainan berupa I Bacté dan I Imun menjelaskan maksud lakon tersebut dalam permainan dalam bentuk pengasosiasian atau perumpamaan. Ketika beberapa peserta tertinggal dan tidak memahami penjelasan maka fasilitator meminta bantuan kepada beberapa peserta yang ditunjuk ke depan dan diulang kembali. Terkadang peserta yang cepat menangkap dia akan hapal ketika di ulangi kembali dan mudah mengulangi arahan fasilitator secara tepat kepada teman-temannya.

c) Masolah (mempraktekkan)

Tujuan dari masolah adalah untuk mempraktekkan permainan secara langsung pasca diberikan materi oleh fasilitator. Yang dilatih adalah daya ingat terhadap materi yang diajarkan sebelumnya, kelincahan gerak (saat melakukan tindakan mengejar I Bacté dan I Bacté gesit mencari perlindungan ke dalam lingkaran), kewaspadaan dalam memperhatikan musuh yakni I Imun, kerjasama antar tim dalam lingkaran, dan ketepatan melakukan sesuatu (dijabarkan saat I Bacté mencari suaka di dalam lingkaran untuk menghindari kejaran I Imun) Ketika melakukan permainan walau anak ada yang tabu saat berpasangan/berpegangan tangan dengan lawan jenis dengan dipengaruhi mitos-mitos didengar anak dari rekan sebayanya yang fasilitator wajib meluruskan. Akibat sudah melakukan tindakan permainan, untuk mengurangi kontaminasi kuman maka dilakukan praktek cuci tangan secara prosedural 6 langkah yang disarankan oleh WHO, anak tampak memahami dan janji mempraktekkannya dalam kehidupan sehari-hari, walau air sempat mati/tidak nyala, peserta tetap mempraktekkan dengan menggunakan hand sanitizer.

d) Uning (mengerti/tahu)

Setelah melakukan permainan, peserta dapat memahami secara substansial faktor penyebab diare yang pernah dialami oleh peserta sebelumnya. Dengan itu diharapkan ke depan dapat menumbuhkan rasa ingat (eling) terhadap kebersihan dan sanitasi diri sendiri dengan membiasakan diri cuci tangan. Bila sudah timbul kebiasaan diharapkan ada proses proteksi dalam memilah makanan yang sekiranya pantas dikonsumsi dan mengerti ada tidaknya potensi untuk menyebabkan diare. Hal itu diketahui dalam tanya jawab evaluasi kepada peserta.

\subsection{Keaktifan program KEDAS}

Dalam hal mencapai tujuan utama KEDAS yakni menciptakan anak sehat bebas diare, maka dibutuhkan peran aktif dalam kegiatan KEDAS ini antara lain melakukan tindakan sosialisasi percontohan kepada anak-anak kelas III di SDN 1 Ubud, lalu melakukan upload video mengenai kegiatan KEDAS ini di saluran youtube yang ditinjau dari jumlah view mencapai 100x dan like sebanyak 40. Selain itu, melalui perantara program KEDAS juga memberikan edukasi mengenai kearifan lokal bali yang pada masa kini mungkin tidak dikenal lagi oleh generasi yang lahir diatas 2000an yakni permainan tradisional Bali dan sejarahnya serta lagu-lagu tradisional anak-anak (sekar rare) sebagai perantara pesan edukasi diare yang dimodifikasi sebagai khasanah budaya yang patut dilestarikan dan diketahui.

\subsection{Peningkatan pengetahuan siswa-siswi di SDN 1 Ubud mengenai bahaya diare dan persepsi terhadap diare}


Peningkatan pengetahuan siswa-siswi kelas III di SDN 1 Ubud dilihat dalam sesi tanya jawab sebelum dan sesudah sosialisasi dalam pelaksanaan metode berlangsung didapatkan adanya perubahan persepsi, seperti perubahan bahwa diare dapat sebabkan oleh banyak hal seperti amoeba, virus dan bakteri, lalu diare ada berbagai jenis, definisi diare secara tepat, mitos-mitos yang ada diluruskan seperti memegang batu dapat menahan feses keluar saat diare, sekiranya dapat dijadikan pemikiran positif peserta program KEDAS untuk pencegahan diare.

\subsection{Keberlanjutan Program KEDAS}

Program KEDAS sudah mendapatkan persetujuan dari SD Negeri 1 Ubud untuk dikombinasikan dalam suatu muatan lokal yakni pelajaran Bahasa Bali yang diajarkan pada setiap kelas III di SDN 1 Ubud. Modul pedoman serta video dokumentasi diserahkan kepada pihak SD Negeri 1 Ubud untuk menjadi pedoman guru mata pelajaran Bahasa Bali dalam melaksanakan program KEDAS secara mandiri berdasarkan modul pedoman dan video yang sudah dimasukkan ke dalam CD dan kanal youtube.

\section{KESIMPULAN}

Memperhatikan pelaksanaan dan hasil program KEDAS dapat disimpulkan bahwa tujuan program pelalianan KEDAS untuk meningkatkan pengetahuan dan wawasan siswa-siswi SD Negeri 1 Ubud tentang pentingnya menjaga kebersihan diri guna mencegah penyakit diare, serta melestarikan lagu dan permainan tradisional. Program ini diharapkan dapat berlanjut dan diterapkan pada semua tingkatan kelas sebagai kegiatan tambahan dalam muatan lokal Bahasa Bali diluar kegiatan belajar mengajar.

\section{UCAPAN TERIMAKASIH}

Ucapan terimakasih kami sampaikan kepada berbagai pihak yang telah membantu pelaksanaan Program KEDAS ini, yakni Direktorat Jenderal Pembelajaran dan Kemahasiswaan Kementerian Riset, Teknologi, dan Pendidikan Tinggi atas bantuan dana kegiatan; Universitas Udayana; serta dr. Desak Putu Yuli Kurniati, M.K.M atas bimbingannya sehingga program KEDAS ini dapat terlaksana dengan baik.

\section{DAFTAR PUSTAKA}

Dinkes Kabupaten Gianyar. 2018. Profil Kesehatan Kabupaten Gianyar Tahun 2017. Gianyar Bali.

Dinkes Prov. Bali. 2017. Profil Kesehatan Provinsi Bali Tahun 2016. Bali.

Rahman, HF., Widoyo, S., Siswanto, H., dkk. 2016. Faktor-Faktor yang Berhubungan Dengan Kejadian Diare di Desa Solor Kecamatan Cermee Bondowoso. NurseLine. 1(1): 24-35.

Depkes RI. 2011. Laporan Nasional: Riset Kesehatan Dasar (Riskesdas) 2010. Jakarta.

WHO. 2017. Diarrhoeal Disease. USA: WHO. 